\title{
Assessment of ecto and endo parasites of Schizothorax plagiostomus inhabiting river Panjkora, Khyber Pakhtunkhwa, Pakistan
}

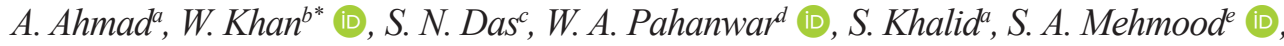

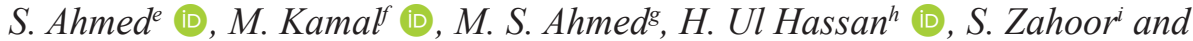 \\ A. Maqbool $^{a}$

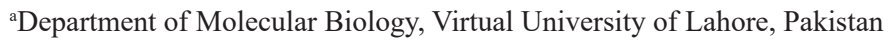 \\ ${ }^{b}$ Department of Zoology, University of Malakand, Lower Dir, Pakistan \\ 'Department of Zoology, University of Sindh, Jamshoro, Pakistan \\ ${ }^{\mathrm{d}}$ Department of Zoology Shah Abdul Latif, University Khairpur Miris Sindh, Pakistan \\ 'Department of Zoology, Hazara University, Mansehra, Pakistan \\ fDepartment of Zoology, University of Karachi, Karachi, Pakistan \\ ${ }^{g}$ Department of Zoology, University of Swabi, Pakistan \\ hDepartment of Zoology, Marine Resource Collection Centre, University of Karachi, Pakistan \\ 'Department of Biotechnology, Virtual University of Pakistan, Pakistan \\ *email: walikhan.pk@gmail.com
}

Received: April 3, 2019 -Accepted: October 8, 2019 - Distributed: February 28, 2021

(With 1 figure)

\begin{abstract}
Fish provides main source of high quality protein to more than one billion people in the world. Fish parasites directly affect the productivity of fish and indirectly on human health. This research was aimed to assess the helminth parasites in Schizothorax plagiostomus (the snow trout) from river Panjkora, KP, Pakistan. A total of 88 fish samples $(n=88)$ were collected from the upper, middle and lower regions of the river through cast nets, hand nets and hooks. All the collected fish samples were examined in the Parasitology Laboratory, Department of Zoology, University of Malakand for helminth parasites during July 2018 to February 2019.Among these fishes nematodes, trematodes, cestodes and acanthocephalan were isolated and identified. Overall prevalence of the fish parasites was $60.22 \%(53 / 88)$. The intensity of the parasite was observed from $1.7 \%$ to $4.61 \%$. Highest prevalence was reported in summer season $86.36 \%$ while lowest in the winter season $36.36 \%$. This study shows that summer season affects the fish business and result in poor quality fish meat with risk of zoonotic diseases. Adults were highly infected $82.25 \%$ while no infection was found in juvenile specimens. Female fish samples had higher prevalence $68.22 \%$ than males $48.22 \%$. Fishes of the lower reaches had highest prevalence $60.22 \%$ than the upper reaches $40.0 \%$. Fish samples with maximum length and weight were highly $76.92 \%$ infected than small sized fish with low body weight. Present study addresses that Rhabdochona schizothoracis in the intestine and Diplozoon paradoxum in gills of snow trout fish has a long term relationship and call as a natural infection in cyprinids and it is zoonotic threat to human.
\end{abstract}

Keywords: snow trout, fish parasites, sub adults, prevalence, zoonotic.

\section{Avaliação de ecto e endoparasitas de Schizothorax plagiostomus habitantes do rio Panjkora, Khyber Pakhtunkhwa, Paquistão}

\section{Resumo}

O peixe é a principal fonte de proteína de alta qualidade para mais de um bilhão de pessoas no mundo. Contudo, parasitas afetam diretamente a produtividade de peixes e, indiretamente, a saúde humana. Esta pesquisa teve como objetivo avaliar os parasitas helmintos em Schizothorax plagiostomus (truta da neve) do rio Panjkora, Khyber Pakhtunkhwa, Paquistão. Foram coletadas 88 amostras de peixes $(n=88)$ dos trechos alto, médio e baixo do rio por meio de redes de arrasto, redes de mão e varas de pesca. Todas as amostras de peixes coletadas foram examinadas no Laboratório de Parasitologia do Departamento de Zoologia, da Universidade de Malakand, quanto a parasitas helmintos durante o período de julho de 2018 a fevereiro de 2019. Entre esses peixes, nematódeos, trematódeos, cestóideos e acantocéfalos foram isolados e identificados. A prevalência geral de parasitas de peixes foi de 60,22\% (53/88). A intensidade do parasita foi observada de 1,7 a 4,61\%. A maior prevalência $(86,36 \%)$ foi relatada no verão, enquanto a menor (36,36\%), no inverno. Este estudo mostra que a temporada de verão afeta o ramo da pesca e resulta em carne de baixa qualidade, 
com risco de doenças zoonóticas. Os adultos foram altamente infectados $(82,25 \%)$, enquanto nenhuma infecção foi encontrada em jovens. As amostras de peixes do sexo feminino apresentaram maior prevalência $(68,22 \%)$ do que as do sexo masculino $(48,22 \%)$. Os peixes coletados no trecho baixo do rio tiveram maior prevalência $(60,22 \%)$ do que os do trecho alto (40\%). Amostras de peixes com comprimento e peso máximos foram altamente infectadas (76,92\%) do que peixes de pequeno porte e baixo peso corporal. O presente estudo aborda que Rhabdochona schizothoracis no intestino e Diplozoon paradoxum em brânquias de peixes de truta da neve possuem uma estreita relação que causa uma infecção natural em ciprinídeos, sendo uma ameaça zoonótica ao ser humano.

Palavras-chave: truta da neve, parasitas de peixes, subadultos, prevalência, zoonótica.

\section{Introduction}

Fish is the main vertebrate that affects life of humans in many forms. According to Shaikh et al. (2011), fish is a source of vitamins, proteins, fats and many other yields such as fish glue, fish oil and fish meal etc. One of the factors responsible for reduction in fish production is parasite. Parasites are vital source of financial losses for aquaculture due to reduction in fish growth and increased mortality (Omeji et al., 2011). According to Khanum et al. (2008) the spreading and frequency of helminthe parasites have been calculated in fresh water fishes from various parts of the world. However minor information is available about the control, distribution and harmful effects. (Bikhovskaya-Pavlovskaya, 1964) have stated that there are 11 classes of invertebrates with 1211 species of fresh water fish parasites such as Nematodes, Cestodes, and acanthocephalan.

Schizothorax plagiostomus belongs to class actinopterygii, order cypriniformes and genus Schizothorax. It was named by Heckel 1838. The Genus Schizothorax has 5 species in Pakistan. Locally it is known as Swati in district Swat, KP. According to Bahuguna et al. (2009), S. plagiostomus is the most common fish, found in snow fed rivers, lakes and tributaries of Himalaya, Afghanistan, China, Pakistan, North-eastern part of India. Its maximum body length is about $60 \mathrm{~cm}$ and weight about $2.5 \mathrm{~kg}$. Sexual maturity is attained at $18-24 \mathrm{~cm}$ body length and spawns twice a year in September-October and March-April at a depth of 10-30 cm (Froese et al., 2011). According to Chen et al. (2002); water current of 2.6-4 m/s, water PH of 7.3-7.5 and dissolved $\mathrm{O}_{2}$ concentrations from $09-15 \mathrm{mg} / \mathrm{l}$ are the optimum conditions for survival and spawning in snow-fed cold water bodies.

\section{Material and Methods}

\subsection{Sampling area}

Dir is situated in the Northern part of Khyber Pakhtunkhwa, Pakistan. It lies between $34^{\circ}-37^{\prime}$ to $35^{\circ}$, $07^{\prime}$ North latitude and $71^{\circ}, 31^{\prime}$ to $72^{\circ}, 14^{\prime}$ East longitudes. This area is almost 823 meters ( 2700 feet) above the sea level. The study area of the Panjkora River is about $180 \mathrm{~km}$ from its origin. Origin of this river is in Kohistan of Dir Upper. It streams in southern direction and flows nearly in the middle of both Districts. It links the River Swat behind Totakan, Malakand District at Bosaaq Bridge (Sharbatti) Figure 1. The name of Panjkora River is due to its 5 key Streams that join the Panjkora at four places (Khan et al., 2019).

\subsection{Fish collection}

Over all 88 fish samples were collected randomly from six monitoring sites (Rabat, Odigram, Timergara, Khazana, Shagukas and Busak) by fishing rods, cast net hand net and by simple hands method in the areas of shallow water on monthly basis. The similar method was also used by Wahab and Yousafzai (2017).

\subsection{Fish preservation, transportation and identification}

The collected fish samples were injected $5 \%$ formalin through different parts such as body wall, anus and mouth for preservation. Each of the containers containing the fish specimen was tagged with; date site and locality of collection. The preserved specimens were transported to the Parasitology Lab, Department of Zoology, University of Malakand for further investigation.

Each fish samples were identified by the methods prescribed by Mirza and Sandhu (2007).

\subsection{Morphometric measurement}

The body weight (BW) and standard length (SL) were measured with the help of electric balance and china tape. The sex of the fish was noted by pressing the abdomen of mature host fish, the extrusion of eggs for female and whitish milt for male identification was used.

\subsection{Dissection, removal and preservation of parasites}

Binocular microscope and magnifier lens were used to investigate external parasites in fins, gills, mouth, nostrils and eyes. Wahab and Yousafzai (2017) protocol was used for Separation and identification. Digeneans, cestodes and acanthocephalans were kept in $70 \%$ ethanol and stained with aceto-alam carmine while monogeneans were fixed and preserved in ammonium-picrate glycerin. The pure glycerin and $70 \%$ alcohol were used in 50:50 parts for preservation of nematodes. For evaporation of alcohol the containers were kept opened for 3 to 5 days. Martins et al. (2007) and Tavares-Dias et al. (2001), protocols were used for processing, counting and Parasite identification.

\subsection{Statistical analysis}

The prevalence, mean intensity and relative density of infection was calculated by the formula given by Ayaz et al. (2011) The relationship between the fish samples examined and that of infected was calculated by applying the Graph Pad Prism Version 5. The value less than $0.05 \%$ at $95 \%$ CI was considered significant. 


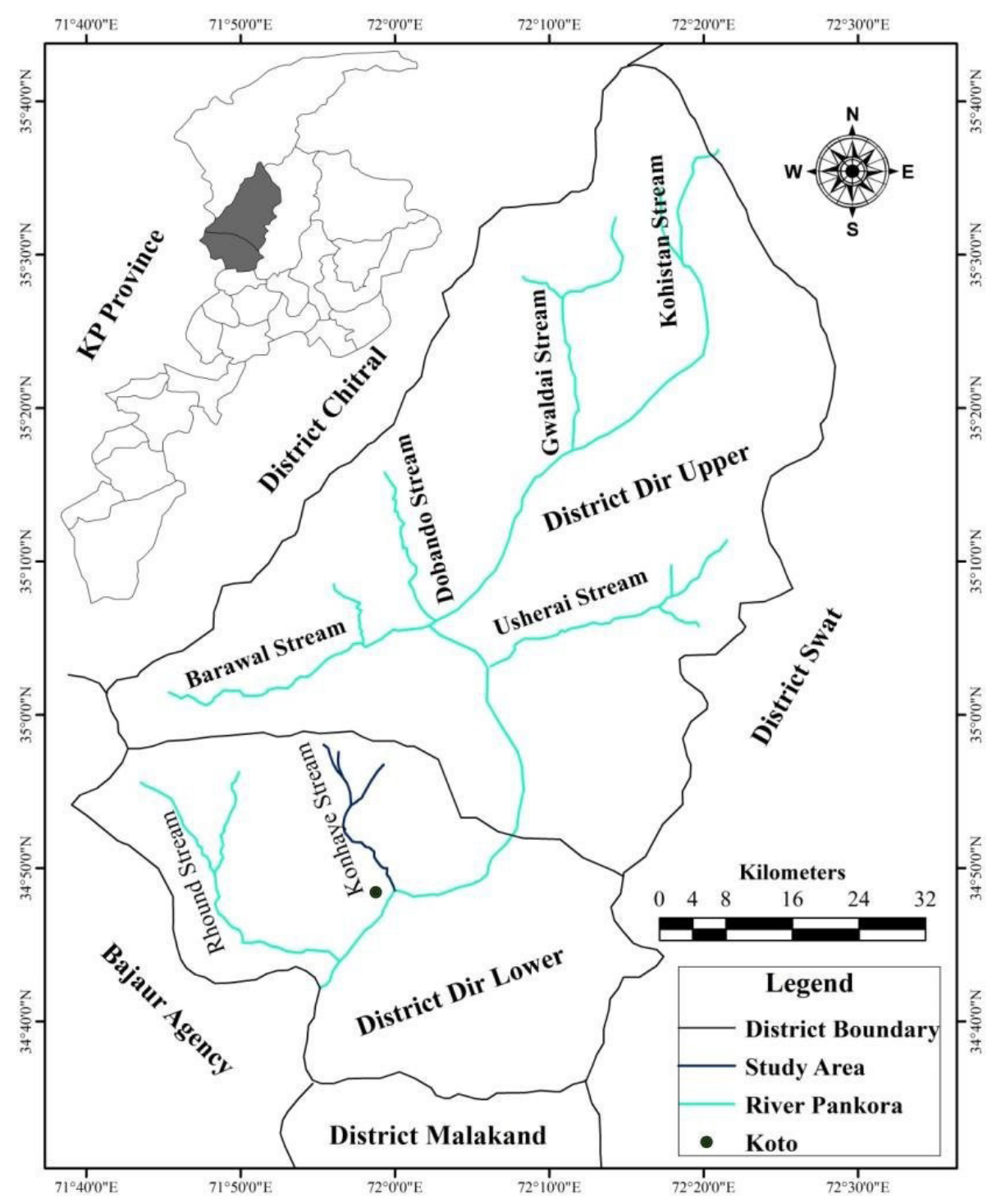

Figure 1. Map presenting sampling area along river Panjkora, Lower Dir, Pakistan.

\section{Results}

The study of ecto and endo helminthes parasites of fish fauna of river Panjkora Dir (L) for the helminthes parasites showed the overall prevalence 60.22 (53/88), intensity (3.03) and relative density (1.82) of fish parasites. From these 88 fishes of $S$. plagiostomus following major parasites were collected.

1. Diplozoon paradoxum. 2. Neochynorhynchous devdevi. 3. Nippotaenia species.

4. Rhabdochona species. 5. Rhabdochona schizothoracis.

The parasite wise prevalence, intensity and relative density were calculated. High prevalence of the parasite R. schizothoracis $20.45 \%$ and the lowest was recorded in $N$. devdevi $4 \%$. High intensity of parasite $R$. schizothoracis 4.61 and the lowest was recorded for Rhabdochona species 1.7 High relative density of parasite $R$. schizothoracis 0.94 and the lowest was recorded for $N$. devdevi 0.09 (Table 1).
High prevalence of parasites was recorded in months of July and August while lowest in February (Table 2).

This record shows that prevalence, intensity and relative density of helminth parasites is high in summer while lowest in winter (Table 3)

This record shows that females have high prevalence, intensity and relative density than males (Table 4)

Adults' fish specimens were found highly infected followed by sub-adults while no infection was observed in juvenile fish specimens (Table 5).

Fish specimens with maximum length and weight were found highly infected than small sized fish with less body weight (Table 6).

The fish collected from lower reaches were found highly $77.14 \%$ infected than the fish from upper reaches $40.0 \%$ of the river (Table 7 ). 
Table 1. Overall and parasite wise prevalence, intensity and relative density of helminth parasites.

\begin{tabular}{lcccccc}
\hline \multicolumn{1}{c}{ Name of Parasite } & $\begin{array}{c}\text { Hosts } \\
\text { examined }\end{array}$ & $\begin{array}{c}\text { Hosts } \\
\text { infected }\end{array}$ & $\begin{array}{c}\text { Prevalence } \\
(\%)\end{array}$ & $\begin{array}{c}\text { parasites } \\
\text { observed }\end{array}$ & Intensity & $\begin{array}{c}\text { Relative } \\
\text { Density }\end{array}$ \\
\hline D. paradoxum & 88 & 16 & 18.18 & 44 & 2.75 & 0.5 \\
N. devdevi & & 04 & 4.54 & 08 & 02 & 0.09 \\
Nippotaenia. specie & & 05 & 5.68 & 09 & 1.8 & 0.10 \\
R. species & & 10 & 11.36 & 17 & 1.7 & 0.19 \\
R.schizothoracis & & 18 & 20.45 & 83 & 4.61 & 0.94 \\
Total & & 53 & 60.22 & 161 & 3.03 & 1.82 \\
\hline
\end{tabular}

Statistical analysis: $\mathrm{P}=0.0001<0.05$ Paired t- test $95 \%$ CI 69.57 to 85.23 .

Table 2. Monthly prevalence of helminth parasites.

\begin{tabular}{lccc}
\hline \multicolumn{1}{c}{ Month } & Hosts examined & Hosts infected & Prevalence \% \\
\hline July 2018 & 11 & 10 & 90.91 \\
August 2018 & 11 & 09 & 81.82 \\
September 2018 & 11 & 08 & 72.73 \\
October 2018 & 11 & 07 & 63.64 \\
November 2018 & 11 & 07 & 63.64 \\
December 2018 & 11 & 05 & 45.46 \\
January 2019 & 11 & 04 & 36.37 \\
February 2019 & 11 & 03 & 27.28 \\
\hline
\end{tabular}

Statistical Analysis: $\mathrm{P}=0.01595 \% \mathrm{CI}=2.33$ to 6.420 .

Table 3. Seasons wise prevalence, intensity and relative density of helminth parasites.

\begin{tabular}{llcccccc}
\hline \multicolumn{1}{c}{ Seasons } & $\begin{array}{c}\text { Host } \\
\text { examined }\end{array}$ & $\begin{array}{c}\text { Host } \\
\text { infected }\end{array}$ & $\begin{array}{c}\text { Prevalence } \\
\text { \% }\end{array}$ & $\begin{array}{c}\text { parasites } \\
\text { recovered }\end{array}$ & Intensity & $\begin{array}{c}\text { Relative } \\
\text { Density }\end{array}$ \\
\hline SUMMER & $\begin{array}{l}\text { July } \\
\text { August }\end{array}$ & 22 & 19 & 86.36 & 85 & 4.47 & 3.86 \\
WUTUMN & $\begin{array}{l}\text { September } \\
\text { October }\end{array}$ & 33 & 22 & 66.66 & 52 & 2.36 & 1.57 \\
$\begin{array}{l}\text { November } \\
\text { December }\end{array}$ & 33 & 12 & 36.36 & 24 & 02 & 0.72 \\
\hline $\begin{array}{l}\text { January } \\
\text { February }\end{array}$ & & & & & & & \\
\hline
\end{tabular}

Statistical Analysis: $\mathrm{P}=0.154495 \% \mathrm{CI}=-10.14$ to 34.07 .

Table 4. Sex wise prevalence, intensity and relative density of helminth parasites.

\begin{tabular}{lcccccc}
\hline Sex of host & $\begin{array}{c}\text { Host } \\
\text { examined }\end{array}$ & Host infected & $\begin{array}{c}\text { Prevalence } \\
\%\end{array}$ & $\begin{array}{c}\text { parasites } \\
\text { recovered }\end{array}$ & Intensity & $\begin{array}{c}\text { Relative } \\
\text { density }\end{array}$ \\
\hline Male & 37 & 18 & 48.64 & 41 & 2.27 & 1.10 \\
Female & 51 & 35 & 68.62 & 120 & 3.42 & 2.35 \\
\hline
\end{tabular}

Statistical Analysis: $\mathrm{P}=0.126595 \% \mathrm{CI}=-29.88$ to 64.88 .

Table 5. Age wise prevalence, intensity and relative density of helminth parasites.

\begin{tabular}{lcccccc}
\hline Age of Host & $\begin{array}{c}\text { Host } \\
\text { Examined }\end{array}$ & Host Infected & Prevalence & $\begin{array}{c}\text { parasites } \\
\text { recovered }\end{array}$ & Intensity & $\begin{array}{c}\text { Relative } \\
\text { density }\end{array}$ \\
\hline Adult & 35 & 29 & 82.25 & 108 & 3.72 & 3.08 \\
Sub adult & 40 & 24 & 60.0 & 53 & 2.20 & 1.32 \\
Juvenile & 13 & 0 & 0 & 0 & 0 & 0 \\
\hline
\end{tabular}

Statistical Analysis: $\mathrm{P}=0.058995 \% \mathrm{CI}=-1,082$ to 24.42 .

Table 6. Length and weight wise prevalence, intensity and relative density of helminth parasites.

\begin{tabular}{lccccccc}
\hline $\begin{array}{c}\text { Standard length } \\
\text { of host(cm) }\end{array}$ & $\begin{array}{c}\text { Body } \\
\text { weight }(\mathbf{g})\end{array}$ & $\begin{array}{c}\text { Host } \\
\text { examined }\end{array}$ & $\begin{array}{c}\text { Host } \\
\text { infected }\end{array}$ & Prevalence & $\begin{array}{c}\text { parasites } \\
\text { recovered }\end{array}$ & Intensity & $\begin{array}{c}\text { Relative } \\
\text { density }\end{array}$ \\
\hline $\mathbf{1 0 - 2 0}$ & $100-150$ & 17 & 03 & 17.64 & 07 & 2.33 & 0.41 \\
$\mathbf{2 0 . 1 - 3 0 . 0}$ & $151-300$ & 32 & 22 & 68.75 & 51 & 2.31 & 1.59 \\
$\mathbf{3 0 . 1 - 4 5 . 0}$ & $301-800$ & 39 & 30 & 76.92 & 103 & 3.43 & 2.64 \\
\hline
\end{tabular}

Statistical Analysis: $\mathrm{P}=0.018795 \% \mathrm{CI}=4.427$ to 17.57 . 
Table 7. Locality wise prevalence (\%), intensity and relative density.

\begin{tabular}{lcccccc}
\hline \multicolumn{1}{c}{ Factor } & $\begin{array}{c}\text { Fish } \\
\text { examined }\end{array}$ & Fish infected & $\begin{array}{c}\text { Prevalence } \\
(\%)\end{array}$ & $\begin{array}{c}\text { parasites } \\
\text { recovered }\end{array}$ & Intensity & $\begin{array}{c}\text { Relative } \\
\text { density }\end{array}$ \\
\hline Upper reaches & 25 & 10 & 40.0 & 18 & 1.80 & 0.72 \\
Middle reaches & 28 & 16 & 57.14 & 45 & 2.81 & 1.60 \\
Lower reaches & 35 & 27 & 77.14 & 98 & 3.62 & 2.80 \\
\hline
\end{tabular}

Statistical Analysis: $\mathrm{P}=0.0289$ 95\% CI= 2.942 to 20.39 .

\section{Discussion}

This study was carried out from July, 2018 to February, 2019 to assess the helminth parasites of Schizothorax plagiostomus (Snow trout) of Panjkora River. In this study 88 fishes of $S$. plagiostomus were collected from various localities of River Panjkora, KP, Pakistan and were examined for the parasites.

The infection rate was detected in term of prevalence as on the basis of months, seasons, sex, age, length, weight, locality and type of parasite. The total prevalence of the fish parasites $60.22 \%$ was determined. Similar study was carried out by Ahmad et al. (2014), they studied 115 snow trout from river Swat for the prevalence of monogenean parasites and find out $93 \%$ infection. In the present research work the highest prevalence value $20.45 \%$ was calculated for $R$. schizothoracis while the lowest was recorded in $N$. devdevi $4.54 \%$. The work of Guillermo Salgado-Maldonado and his co-workers also approves our work for patterns of taxonomical structure of helminth parasites of freshwater fishes and for confirmation of that nematodes and trematodes are most abundant while acanthocephalan and cestodes were in less abundance (Maldonado et al., 2011). In our study high relative density of parasite $R$. schizothoracis $0.94 \%$ was followed by $D$. paradoxum $0.5 \%$ and the lowest was recorded of N. devdevi $0.09 \%$ (Table 1). Similar data was also reported from different parts of the world. Ahmad et al. (2014) reported two species of Rhabdochona as R. schizothoracis with $22.8 \%$ and $R$. charsaddiensis with $10.8 \%$ infection rate. Leela and Rao (2014) studied goldfish in India and reported $R$. garuaiin with $40.6 \%$ infection rate, 3.14 mean intensity and 1.40 relative densities. In the present study (Table 1) the high intensity of parasite R. schizothoracis $4.61 \%$ was recorded, followed by $D$. paradoxum $2.75 \%$ and the lowest was that of R. species 7\%.

In this study high prevalence of parasites was recorded in month of July $90.91 \%$ and August $81.82 \%$ while the lowest was in February $27.28 \%$. The variations in prevalence were due to seasonal changes and environmental factors. (Table 2). In a similar study carried out by Parween and Rahman (2000) the highest rate of infection $22.73 \%$ was recorded in August and the lowest in November 4.55\%. Like our findings they also noted that the maximum prevalence of the parasites was noticed in the intestines and the lowest in the gills. In the current study prevalence of helminth parasites is high 86.36 in summer and lowest 36.36 in winter similar to Khurshid and Ahmad (2014) when they had noted highest prevalence in summer followed by autumn and least was noted in winter as $39.5 \%, 19 \%$ and $3.8 \%$, respectively in S. labiatus. It shows that temperature of water has no indistinct effect on the occurrence of nematode parasites.

In the present study sex wise prevalence of S. plagiostomus was noted. This record showed that females had high prevalence $68.62 \%$ than males $48.64 \%$. (Table 4 ) Findings of the present research is similar with Omeji et al. (2014).

In the recent study (Table 5) adults fish specimens were found highly $82.25 \%$ infected followed by sub-adults $60.0 \%$ while no infection was observed in juvenile fish specimens. Similarly, Shakir et al. (2006) studied a catfish Sperata sarwari from Mangla Lake for Helminth parasite and was noted that the large sized fishes showed higher prevalence $(39.13 \%)$ rate than the small sized fishes (28.85\%). Length and weight are directly related to the prevalence of parasites. In present study (Table 6) it was observed that fish specimens with maximum length and weight were found highly $76.92 \%$ infected and small sized fish with less body length and low weight show little prevalence i.e. $17.64 \%$.According to Omeji et al. (2014) parasitic infection increases with the increase of length and weight. In the current study (Table 7) fishes collected from lower reaches were highly $77.14 \%$ infected than middle and upper reaches of the river. Similar work was carried out by Crisp and his co-workers in South-eastern Mexico. They concluded that the infection rate of various helminth parasites show variation in the river Papaloapa basin to the Yucatan Peninsula (Crisp et al., 2001)

\section{Acknowledgements}

Fish farmers of the region were appreciated for co-operation in trapping the fish specimens. The authors declared that they have no conflict of interest.

\section{References}

AHMAD, R., AYAZ, S., SHAMS, S. and AHMAD, R., 2014. Prevalence and morphology of helminth parasites of fish from river Swat, Khyber Pakhtunkhwa. Pakistan Journal of Agricultural Research, vol. 27, no. 2, pp. 142-148.

AYAZ, S., KHAN, S., KHAN, S.N., BIBI, F., SHAMAS, S. and AKHTAR, M., 2011. Prevalence of zoonotic parasites in drinking water of three districts of Khyber Pakhtunkhwa Province, Pakistan. Pakistan Journal of Life and Social Sciences, vol. 9, no. 1, pp. 67-69.

BAHUGUNA, S.N., NEGI, R.S. and UPADHYAY, M.K., 2009. Ex-situ study on density dependent survival after handling Yolk Sac Larvae of snow trout, Schizothorax plagiostomus Heckel. Our Nature, vol. 7, no. 1, pp. 146-150. http://dx.doi.org/10.3126/ on.v7i1.2562. 
BIKHOVSKAYA-PAVLOVSKAYA, I.E., 1964. Key to the parasites of fresh-water fishes in the USSR. Moscow \& Leningrad: Izdatelstvo Akademii Nauk SSSR, 776 p.

CHEN, G., CAO, P., and GOEDDEL, D.V., 2002. TNF-Induced recruitment and activation of the IKK complex require $\mathrm{Cdc} 37$ and Hsp90. Molecular Cell, vol. 9, no. 2, pp. 401-441.

CRISP, M.D., LAFFAN, S., LINDER, H.P. and MONRO, A., 2001. Endemism in the Australian flora. Journal of Biogeography, vol. 28, no. 2, pp. 183-198. http://dx.doi.org/10.1046/j.13652699.2001.00524.x.

FROESE, R., TSIKLIRAS, A.C. and STERGIOU, K.I., 2011. Editorial note on weight-length relations of fishes. Acta Ichthyologica et Piscatoria, vol. 41, no. 4, pp. 261-263. http:// dx.doi.org/10.3750/AIP2011.41.4.01.

KHAN, W., KHAN, J., KHAN, N., IQBAL, R., ULLAH, A., GHAFFAR, R., MEHMOOD, S.A., AHMAD, S., KHAN, S. and ULLAH, F., 2019. Soil-transmitted helminth infections in school children of three districts of Malakand region, Khyber Pakhtunkhwa, Pakistan. Pakistan Journal of Pharmaceutical Sciences, vol. 32, no. 2, pp. 799-803. PMid:31103975.

KHANUM, H., FERDOWS, J. and FARHANA, R., 2008. Community of helminth parasites in Rita rita (Hamilton Buchanun). Journal of Bio-Science, vol. 16, pp. 133-135. http://dx.doi. org/10.3329/jbs.v16i0.3757.

KHURSHID, I. and AHMAD, F., 2014. Parasitic burden of some fresh water fishes of river Sindh in Kashmir in relation to season. International Journal of Innovative Research in ScienceEngineering and Technology, vol. 3, pp. 15688-15690.

LEELA, B. and RAO, K.R., 2014. Nematode parasites in a freshwater 335 Fish Glossogobius giuris (Hamilton-Buchanan, 1822) at lower Manair Dam, Karimnagar Dt. Andhra Pradesh, India. IOSR Journal of Pharmacy and Biological Sciences, vol. 9, no. 2, pp. 37-40.

MALDONADO, G., CASPETA-MANDUJANO, J.M., MORAVEC, F., SOTO-GALERA, E., RODILES-HERNÁNDEZ, R., CABAÑAS-CARRANZA, G. and MONTOYA-MENDOZA, J., 2011. Helminth parasites of freshwater fish in Chiapas, Mexico.
Parasitology Research, vol. 108, no. 1, pp. 31-59. http://dx.doi. org/10.1007/s00436-010-2035-3. PMid:20981446.

MARTINS, M.L., GHIRALDELLI, L., GARCIA, F., ONAKA, E.M. and FUJIMOTO, R.Y., 2007. Experimental infection in Notodiaptomus sp. (Crustacea: Calanoida) with larvae of Camallanus sp. (Nematoda: Camallanidae). Arquivo Brasileiro de Medicina Veterinária e Zootecnia, vol. 59, no. 2, pp. 382-386. http://dx.doi.org/10.1590/S0102-09352007000200018.

MIRZA, M.R. and SANDHU, A.A., 2007. Fishes of the Punjab Pakistan. Lahore: Polymer Publication,Urdu Bazar.

OMEJI, S., SOLOMON, S.G. and IDOGA, E.S., 2011. A comparative study of the common protozoan parasites of Clarias gariepinus from the wild and cultured environments in Benue State, Nigeria. Journal of Parasitology Research, vol. 2011, pp. 2011. http://dx.doi.org/10.1155/2011/916489. PMid:22028952.

OMEJI, S., TIAMIYU, L.O., ANNUNE, P.A. and SOLOMON, S.G., 2014. Ecto and intestinal parasites of Malapterurus electricus from upper river benue. Journal of Global Biosciences, vol. 3, no. 6 , pp. $895-903$

PARWEEN, S. and RAHMAN, M.R., 2000. Distribution of helminth parasites in different organs and their monthly rate of infestation in three freshwater fishes of Rajshahi. University Journal of Zoology. Rajshahi University, vol. 19, pp. 67-72.

SHAIKH, G.S., KHAN, A. and BILQEES, F.M., 2011. A new trematode of the genus Genarchopsis Ozaki, 1925 from freshwater fish of Sindh, Pakistan. Pakistan Journal of Zoology, vol. 43, no. 5

SHAKIR, H.A., KHAN, A.M. and ABID, M., 2006. The prevalence of cestode infection in a freshwater catfish, Sperata sarwari. Punjab University Journal of Zoology, vol. 21, no. 1-2, pp. 41-47.

TAVARES-DIAS, M., MORAES, F.R.D., MARTINS, M.L. and KRONKA, S.N., 2001. Fauna parasitária de peixesoriundos de pesque-pagues do município de Franca, São Paulo, Brasil. II. Metazoários. Revista Brasileira de Zoologia, vol. 18, suppl. 1, pp. 81-95. http://dx.doi.org/10.1590/S0101-81752001000500006.

WAHAB, A. and YOUSAFZAI, A.M., 2017. Cyprinid fauna (Cypriniformes) of River Panjkora, district Lower Dir, Khyber Pakhtunkhwa, Pakistan. Pure and Applied Biology, vol. 6, no. 4, pp. 1354-1365. http://dx.doi.org/10.19045/bspab.2017.600146. 